\title{
Synchronization of Boron Application Methods and Rates is Environmental Friendly Approach to Improve Quality Attributes of Mangifera indica L. on Sustainable Basis
}

\section{Muhammad Mehboob Hassan Khan}

Department of Soil Science, Faculty of Agricultural Sciences and Technology, Bahauddin Zakariya University, Multan, 60800 Pakistan

Niaz Ahmed

Department of Soil Science, Faculty of Agricultural Sciences and Technology, Bahauddin Zakariya University, Multan, 60800 Pakistan

\section{Muhammad Arif Ali}

Department of Soil Science, Faculty of Agricultural Sciences and Technology, Bahauddin Zakariya University, Multan, 60800 Pakistan

\section{Subhan Danish ( $\nabla$ sd96850@gmail.com )}

Department of Soil Science, Faculty of Agricultural Sciences and Technology, Bahauddin Zakariya University, Multan, 60800 Pakistan

\section{Milan Skalicky}

Department of Botany and Plant Physiology, Faculty of Agrobiology, Food and Natural resources, Czech University of Life Sciences Prague, Kamycka 129, 16500 Prague, Czechia

\section{Shah Fahad}

Hainan Key Laboratory for Sustainable Utilization of Tropical Bioresource, College of Tropical Crops, Hainan University, Haikou 570228, China

\section{Rahul Datta}

Department of Geology and Pedology, Faculty of Forestry and Wood Technology, Mendel University in Brno, Zemedelska1, 61300 Brno, Czech Republic

\section{Mohamed M. Hassan}

Department of Biology, College of Science, Taif University, P.O. Box 11099, Taif 21944, Saudi Arabia

\section{Marian Brestic}

Department of Plant Physiology, Slovak University of Agriculture, Nitra, Tr. A. Hlinku 2, 94901 Nitra, Slovak Republic

\section{Ayman EL Sabagh}

Department of Agronomy, Faculty of Agriculture, University of Kafrelsheikh, 33516, Egypt 


\section{Research Article}

Keywords: Acidity, Fats, Micronutrients, Macronutrients, Protein contents, Phenolics contents, Total soluble solids

Posted Date: January 4th, 2021

DOI: https://doi.org/10.21203/rs.3.rs-135113/v1

License: (c) (i) This work is licensed under a Creative Commons Attribution 4.0 International License.

Read Full License 


\section{Abstract}

Deficiency of micronutrients in soil is one of major cause for poor quality of mango fruit and yield. In addition, consumption of such diet also causes deficiency of micronutrients in humans. Among different micronutrients deficiency of boron is very common. It adversely affects flowering and pollen tube formation, thus played key role in decreasing the yield and quality attributes of mango. To overcome such problem, soil and foliar application of B is considered the efficacious methods. That's why under changing climatic condition, a field experiment was conducted to explore the most suitable method and application rate of $B$ in mango under current climatic scenario. There were nine treatments applied in three replications. Results showed that application of $\mathrm{T} 8=\mathrm{RD}+\mathrm{Borax}\left(75 \mathrm{~g} \mathrm{plant}^{-1}\right.$ as basal application $)+\mathrm{H}_{3} \mathrm{BO}_{3}\left(0.8 \%\right.$ as foliar spray) and $\mathrm{T} 9=\mathrm{RD}+\mathrm{Borax}\left(150 \mathrm{~g} \mathrm{plant}^{-1}\right.$ as basal application $)+\mathrm{H}_{3} \mathrm{BO}_{3}$ ( $0.8 \%$ as foliar spray) significantly enhanced nitrogen, potassium, proteins, ash, fats, fiber and total soluble solids in mango as compared to control. A significant decrease in sodium, total phenolics contents, antioxidant activity and acidity as citric acid also validated the efficacious functioning of $\mathrm{T} 8=\mathrm{RD}+$ Borax $\left(75 \mathrm{~g} \mathrm{plant}^{-1}\right.$ as basal application $)+\mathrm{H}_{3} \mathrm{BO}_{3}(0.8 \%$ as foliar spray) and $\mathrm{T} 9=\mathrm{RD}+\mathrm{Borax}(150 \mathrm{~g}$ plant $^{-1}$ as basal application $)+\mathrm{H}_{3} \mathrm{BO}_{3}(0.8 \%$ as foliar spray)over control. In conclusion T8=RD+Borax $(75 \mathrm{~g}$ plant ${ }^{-1}$ as basal application $)+\mathrm{H}_{3} \mathrm{BO}_{3}\left(0.8 \%\right.$ as foliar spray) and $\mathrm{T} 9=\mathrm{RD}+$ Borax $\left(150 \mathrm{~g} \mathrm{plant}^{-1}\right.$ as basal application) $+\mathrm{H}_{3} \mathrm{BO}_{3}(0.8 \%$ as foliar spray) is an effective strategy to improve quality attributes of mango under changing climatic situation.

\section{Introduction}

Micronutrients deficiency is a major concern in humans health globally especially among women and children's in under developed regions ${ }^{1}$. It is also required for optimum growth and regulation of metabolic processes in plants, in small quantity ${ }^{2}$.Unfortunately, a large number of environmental factors i.e., soil texture and structure, contents of calcium carbonate, soil $\mathrm{pH}$, aluminum and iron oxides, nutritional status, organic matter, soil fauna and flora, bicarbonate and sulfur content, redox potential of soil, poor irrigation and management practices influence decreased micronutrients uptake by roots in plants. These factors also restrict the translocation and accumulation of micronutrient inconsumable parts of crops thus adversely affect yield ${ }^{3,4}$.

To overcome the deficiency of micronutrients fertilizer application is soil is one of common method. These micronutrients can be added in soil via band placement, broadcasting or fertigation ${ }^{5-7}$. On the other hand, foliar application of nutrients is also an important crop strategy to optimized crop yields and micronutrients in edible parts ${ }^{3,8}$.Several studies have shown that foliar application of nutrients ${ }^{9} \mathrm{can}$ increase growth and yield of crops ${ }^{3,10}$.

Among different micronutrients, boron $(B)$ is an essential. It is required by all plants. Although $B$ is component of cell walls, limited literature is documented on its biochemical functions. In maintenance of membrane function B played an imperative role ${ }^{11}$. It also supports metabolic activities in plants. 
However, higher uptake of $B$ in plants can also cause severe toxicity ${ }^{12}$. Boron occurs as uncharged boric acid $[\mathrm{B}(\mathrm{OH}) 3]$ in soil solution. Fruit setting and retention percentage of fruit are attributed to boron $(\mathrm{B})$ concentration in fruit ${ }^{13}$.

Less availability of B in floral structure, resulted in less fruit setting from flowers. It also minimized percent fruit retention on panicle ${ }^{3}$. Balance $B$ uptake increases thickness of cell wall thickness through specific complexes. In addition, increase in flower number and retention, germination, pollen tube elongation, seed and fruit development are other benefits associated with balance $B$ uptake. Translocation of photosynthates and less IAA oxidation are also controlled by $\mathrm{B}^{14}$.

Mango (Mangifera indica L.) is a popular fruit crop of family Anacardiaceae. It is cultivated in tropical and subtropical areas of world. Due to excellent flavour, delicious taste and pleasant fragrance many people called it king of fruits. However, less fruit setting and retention is a serious problem in mango. During early development stages fruitlet abscission is complex physiological process. Role of micronutrients are very important in this regard. Their acute deficiencies some time causes lower fruit yield and quality of mango ${ }^{15}$. Among micronutrients, $B$ plays a vital role in hormone movement, flowering, activate salt absorption, pollen germination fruiting process and pollen tube growth ${ }^{16}$. That's why current study was conducted with aim to explore the improvement in quality and yield attributes of mango amended with $B$ fertilizer under $B$ deficient conditions. It is hypothesized that combined application of B i.e., foliar and soil is a better approach than sole application for the improvement in quality and yield characteristics of mango in B deficiency conditions. Current study will help the farming community for management of $B$ in mango trees for the achievement of better fruit quality and yield.

\section{Methods}

\subsection{Treatment Plan}

There were 9 treatments with 3 replication following randomized complete block design. The treatments includes: $\mathrm{T}_{1}$ : Recommended dose $(\mathrm{RD})$ of $\mathrm{NPK}+$ Borax $\left(0 \mathrm{~g} \mathrm{plant}^{-1}\right.$ as basal application $)+\mathrm{H}_{3} \mathrm{BO}_{3}(0 \%$ as foliar spray), $\mathrm{T}_{2}: \mathrm{RD}+$ Borax (75 $\mathrm{g}_{\text {plant }}{ }^{-1}$ as basal application $)+\mathrm{H}_{3} \mathrm{BO}_{3}\left(0 \%\right.$ as foliar spray), $\mathrm{T}_{3}: \mathrm{RD}+$ Borax (150 g plant ${ }^{-1}$ as basal application) $+\mathrm{H}_{3} \mathrm{BO}_{3}\left(0 \%\right.$ as foliar spray), $\mathrm{T}_{4}: \mathrm{RD}+$ Borax $\left(0 \mathrm{~g} \mathrm{plant}^{-1}\right.$ as basal application $)+\mathrm{H}_{3} \mathrm{BO}_{3}\left(0.4 \%\right.$ as foliar spray), $\mathrm{T}_{5}$ : RD + Borax $\left(75 \mathrm{~g} \mathrm{plant}^{-1}\right.$ as basal application $)+$ $\mathrm{H}_{3} \mathrm{BO}_{3}\left(0.4 \%\right.$ as foliar spray), $\mathrm{T}_{6}$ : $\mathrm{RD}+$ Borax (150 g plant $^{-1}$ as basal application $)+\mathrm{H}_{3} \mathrm{BO}_{3}(0.4 \%$ as foliar spray), $\mathrm{T}_{7}: \mathrm{RD}+$ Borax $\left(0 \mathrm{~g} \mathrm{plant}^{-1}\right.$ as basal application $)+\mathrm{H}_{3} \mathrm{BO}_{3}\left(0.8 \%\right.$ as foliar spray), $\mathrm{T}_{8}: \mathrm{RD}+$ Borax (75 g plant ${ }^{-1}$ as basal application) $+\mathrm{H}_{3} \mathrm{BO}_{3}\left(0.8 \%\right.$ as foliar spray) and $\mathrm{T}_{9}: \mathrm{RD}+$ Borax (150 g plant ${ }^{-1}$ as basal application $)+\mathrm{H}_{3} \mathrm{BO}_{3}(0.8 \%$ as foliar spray) .

\subsection{NPK application}


Macronutrients application was done at the rate of $1.5(\mathrm{~N}), 1(\mathrm{P}), 1(\mathrm{~K}) \mathrm{kg} / \mathrm{plant} /$ year respectively. All $\mathrm{P}$ amount $(1 \mathrm{~kg})$ while half $\mathrm{N}(0.75 \mathrm{~kg})$ and $\mathrm{K}(0.50 \mathrm{~kg})$ were added at end of July. However, remaining half $\mathrm{N}$ and $\mathrm{K}$ were added before $1^{\text {st }}$ week of February ${ }^{27}$.

\subsection{Boron application}

Soil applicationwill be done before flowering; Foliar spray will be done twice a year; first at inflorescence stage and second when fruit attained pea size. At the end of experiment, soil and leaf samples will be collected, stored and processed for analysis ${ }^{3}$.

\subsection{Plants sampling}

For collection of leaf samples, 15 healthy mango plants were randomly nominated from the orchard. About 20 developed leaves (4-6 months old) were collected randomly from all the sides of the canopy of mango plant from the fruit bearing and non-fruit bearing twigs. Samples were collected during the months of July/August. Then leaves were washed out with distilled water and dried in oven at temperature $70^{\circ} \mathrm{C}$ for 48 hours. Oven dried material was grind with the help of John Wiley mill and then passed through a 40-mesh screen.

\subsection{Plant analyses}

The leaf samples were digested in diacid mixture and the concentration of $\mathrm{B}^{28}$. Zinc and iron were determined and analyzed using spectrophotometer /atomic absorption spectrophotometer ${ }^{29}$. Leaf samples were digested and run with spectrophotometer for $\mathrm{P}^{30}$ and flame photometer for $\mathrm{K}$ and $\mathrm{Na}{ }^{31}$. Kjeldahl's method was used for nitrogen analysis ${ }^{32}$.

\subsection{Fruit Retention}

For assessment of fruit retention an area of $1.0 \mathrm{~m}^{2}$ from all four sides of the tree was marked. Fruit retention was observed between mustard stages to the marble stage by adopting the standard protocol.

\subsection{Acidity}

Titratable acidity as percent citric acid was assessed in fresh mango juice. Titration of sample at $\mathrm{pH} 8.2$ was done with sodium hydroxide $(0.1 \mathrm{~N})^{33}$.

Acidity $(\%)=\left(\frac{\text { Volume of } 0.1 \mathrm{~N} \mathrm{NaOH}(\mathrm{mL}) \times 0.067}{\text { Volume of Juice }(\mathrm{mL})}\right) \times 100$

\subsection{Total Soluble Solids (TSS)}

For total soluble solids (Brix॰) "Medline Scientific Ltd. digital hand refractometer model SELECT045" was used. From each fruit, $20 \mathrm{~g}$ pulp was collected. It was homogenized for 60 seconds in $80 \mathrm{~mL}$ distilled water. Finally, $1 \mathrm{ml}$ of homogenate was placed on refractometer for TSS assesment ${ }^{34}$. 


\subsection{Sugar Contents}

Total sugar content of mango pulp was determined calorimetrically by the anthrone method ${ }^{35}$.

\subsection{Total Phenolic Contents and Vitamin C}

The total phenolic content of the liqueurs was determined by the spectrophotometric method with FolinCiocalteu ${ }^{36}$.Vitamin $\mathrm{C}$ was assessed in mango fruit by adopting the methodology of Spencer et al. ${ }^{37}$.

\subsection{Statistical analysis}

Collected data was examined statistically by applying analysis of variance (ANOVA) and Tukey's test at $p$ $\leq 0.05$. Statistical computer software package (Origin 2020b) was used for the statistical analysis ${ }^{38}$.

\section{Results}

\section{1. $N$, $P$ and $K$ of Mango}

Effects of treatments was significant on nitrogen $(N)$, phosphorus $(P)$ and potassium $(K)$ concentration of mango. Treatments T8 and T9 were significant for improvement in $\mathrm{N}$ of mango from control. Significant increase in $\mathrm{N}$ was also noted in T5 and T6 from control for $\mathrm{N}$ in mango. Application of T7, T3, T2 and T4 also remained significant for $\mathrm{N}$ improvement over control (Fig. 1). In case of phosphorus, a significant decrease was observed by the application of different levels of $\mathrm{Zn}$. No significant change was observed in T3, T6 and T9 where highest level of $Z n$ was applied. It was noted that phosphorus concentration was also significantly higher in T1, T4 and T7 over T2, T5 and T8 (Zn applied) (Fig. 2). Treatments T6, T8 and T9 remained significantly better than T1 for $\mathrm{K}$ concentration. Application of T3, T7 and T5 were also significantly different over T1 for $\mathrm{K}$ concentration (Fig. 3). Furthermore, for $\mathrm{K}$ concentration, $\mathrm{T} 2$ and $\mathrm{T} 4$ different significantly better from T1. Maximum increase in N, P and $\mathrm{K}$ was noted in T9, T1 and T9 as compared to $\mathrm{T} 1, \mathrm{~T} 9$ and $\mathrm{T} 1$ respectively. Pearson correlation showed that $\mathrm{N}$ was positive and significant in correlation with $\mathrm{K}$. However, negative significant correlation was noted between $\mathrm{N}$ and P. Principal component analysis showed that $\mathrm{N}$ and $\mathrm{K}$ were closely associated with T8 and T9. However, $\mathrm{P}$ was more closely associated with T1 and T4.

\subsection{Na, Ca and Fe of Mango}

Effects of treatments was significant on sodium ( $\mathrm{Na})$, calcium $(\mathrm{Ca})$ and iron $(\mathrm{Fe})$ concentration of mango. Treatments $\mathrm{T} 1$ and $\mathrm{T} 4$ were significant for improvement in $\mathrm{Na}$ of mango from control. Significant increase in $\mathrm{Na}$ was also noted in T2, T3 and T5 from control for $\mathrm{Na}$ in mango (Fig. 4). Application of T6, T7, T8 and T9was non-significant for $\mathrm{Na}$ improvement with each other. In case of calcium, a significant decrease was also observed by the application of different levels of Zn. No significant change was observed among T6 and T8, however, minimum Ca was noted in T9 where highest level of Zn was applied (Fig. 5). Application of T2, T3, T4 and T5 were also significantly decrease Ca over T1. Furthermore, for Fe concentration, all the treatments showed significant decline as compared to T1 (Fig. 
6). Maximum decrease in $\mathrm{Zn}, \mathrm{Ca}$ and Fe was noted in T9 as compared to T1. Pearson correlation showed that $\mathrm{Ca}$ was positive and significant in correlation with Fe and $\mathrm{Na}$. Similarly, positive significant correlation was noted between $\mathrm{Na}$ and Fe. Principal component analysis showed that $\mathrm{Na}, \mathrm{Fe}$ and $\mathrm{Ca}$ were closely associated with $\mathrm{T} 2$.

\subsection{Protein, Fats, Ash and Fiber contents of Mango}

Effects of treatments was significant on protein, fats, ash and fiber contents of mango. Treatments T9 were significant for improvement in protein contents of mango from T1 control. Significant increase in protein was also observed in T7 and T8 from control for protein contents in mango. Application of T2 to T5 was significant as well for protein contents improvement with T1 (Fig. 7). In case of ash content, a significant increase was noted in T9 and T8 over T1. No significant change was observed among T8 and T7, for ash contents with each other. However, T5 and T6 also differed significantly for ash contents over T1 control. Statistical analyses also confirmed that T2 and T4 were non-significant over control T1 for ash contents in mango (Fig. 8). Treatments T6 and T9 remained significantly better than T1 for fat contents. Application of T6, T5 and T8 were also significantly increase fat contents over T1. It was observed that T2 did not differ significantly for fat contents in mango over T1 (Fig. 9). For fiber contents of mango, T5, T7, T8 and T9 were statistically alike with each other but were significantly different over control T1. Application of T3, T4 and T6 also remained significant for improvement in fiber contents over T1. However, T2 remained non-significant for fiber contents over T1 control (Fig. 10). Maximum increase in protein, fats, ash and fiber contents was noted in T9 as compared to T1. Pearson correlation showed that protein, fats, ash and fiber contents were positive and significant in correlation with each other. Principal component analysis showed that protein, fats, ash and fiber contents were closely associated with T8.

\subsection{Moisture, TSS, TPC and antioxidant activity in Mango}

Effects of treatments was significant on moisture, TSS, TPC and antioxidant activity in mango.

Treatments T9, T8, T6 were significant for improvement in moisture contents of mango from T1 control. Significant increase in protein was also observed in T7 and T8 from control for protein contents in mango. Application of T3, T4and T5 was significant as well for moisture contents improvement from T1. Application of T2 and T7 were statistically alike with each other but differed significantly from T6 control for moisture contents (Fig. 11). In case of total soluble solids (TSS), a significant increase was noted in T6 and T9 over T1. No significant change was observed among T2 and T1, for TSS with each other (Fig. 12). However, $T 3, T 4$ and $T 5$ also differed significantly for TSS over T1 control. Statistical analyses also confirmed that T8 and T9 were non-significant with each other but significant over control T1 for total phenolic contents (TPC) in mango (Fig. 13). Treatments T6 and T7 cause significant decrease in TPC than T1. Application of T4 and T5 were also significantly decrease TPC over T1. No significant change in 
TPC among T1, T2 and T3. Furthermore, for antioxidants activity, all the treatments showed significant decline as compared to T1, T4 and T7 (Fig. 14). Maximum increase in moisture, TSS, TPC and antioxidant activity was noted in T9 as compared to T1. Pearson correlation showed that moisture and TSS were positive and significant in correlation with each other. However, antioxidant activity and TPC showed negative significant correlation with moisture, TSS. Principal component analysis showed that moisture, TSS and antioxidant activity were closely associated with T6, T8 and T9, T8 and T1 and T7respectively.

\subsection{Acidity, SC and Vitamin C in Mango}

Effects of treatments was significant on acidity, sugar content (SC) and vitamin $\mathrm{C}$ in mango. All the treatments significantly decreased acidity of mango from T1 control except T4 and T7 (Fig. 15). In case of SC a significant increase was noted in T9 over T1. No significant change was observed among T5, T6 and T8 but differed significantly from T1, for SC. In addition, T2, T3 and T4 also differed significantly for SC over T1 control (Fig. 16). Statistical analyses also confirmed that T2, T4 and T7 were non-significant with each other and T1 control for vitamin $\mathrm{C}$ in mango (Fig. 17). Treatments T3, T5, T6, T8 and T9 significantly decreased vitamin $\mathrm{C}$ than T1. Maximum increase in sugar content (SC) was noted in T9 as compared to T1. However, T9 gave maximum decrease in acidity and vitamin $\mathrm{C}$ in mango as compared to T1. Pearson correlation showed that sugar content showed negative significant correlation with acidity and vitamin C (Fig. 18). Principal component analysis showed that acidity, sugar content (SC) and vitamin $C$ were closely associated with $T 4, T 6$ and $T 7$ respectively (Fig. 19).

\section{Discussion}

Optimum uptake of B is important not only for normal growth but also for enhancement of quality attributes in fruiting plants ${ }^{2}$. A large number of studies indicated that $B$ played an immense role in better uptake of nitrogen. Plants showed minimum nitrate reductase (NR) activity. It is also sensitive towards accumulation of nitrate when there is severe deficiency of $\mathrm{B}^{17}$. In addition of $\mathrm{N}$, better uptake of $\mathrm{B}$ also facilitates the better $P$ and $K$ intake in plants. It increases the permeability of roots, which facilitate the $P$ and $\mathrm{K}$ uptake. However, application of $\mathrm{B}$ as treatment also decrease the uptake of $\mathrm{Ca}{ }^{18,19}$. Our findings also justified these arguments. Results showed that increasing level of $B$ also enhanced the N, P and K concentration of Mango. It also decreases the Ca uptake in mango might be due to its antagonistic relationship with $\mathrm{B}$. It plays a key role in pollen germination, pollen tube formation and anthor development. Hence, limited number of flowers, poor fruit quality and yield are major drawbacks of $B$ deficiency ${ }^{20}$. Application of boron as foliar, become the part of plants through superiority of phloem filter plates in the basipetal flow of sucrose. It stabilizes the nuclear membrane and ribonucleic acid metabolism, thus played imperative role in assimilation of sugar contents ${ }^{2}$. Results of current study also 
in agreement with these findings. Foliar application of micronutrient B and $\mathrm{Zn}$ as T9 significantly enhanced the sugar contents of mango. It has been observed that B has key role in phenolic metabolism. It activates enzyme phenylalanine ammonium-lyase (PAL) under deficiency conditions which significantly increased phenolic. Higher accumulation phenolic are catalytic oxidized by activity of polyphenoloxidase (PPO) enzyme. Such oxidation resulted in the production of quinones that decrease the integrity of cell membrane ${ }^{21}$. Findings of current study also signifies that phenolics contents were decreased by increasing soil and foliar application of $\mathrm{B}$. The reduction in phenolic was might be due to better uptake of $B$ and alleviation of $B$ deficiency in mango plants. In plant cell wall growth deficiency of $B$ also decrease glycoproteins. Most of surface proteins bind with membrane through glycosylphosphatidylinositol anchor such as arabinogalactan proteins (AGP). These glycosylphosphatidylinositol anchor such as arabinogalactan proteins (AGP) provide bindings sites for putative B-binding structures ${ }^{22,23}$. Same kind of changes are also observed in pollen tubes where cell wall is made up of pectins. Results of current study are also in line with above arguments. Highest application rate of B significantly increases the proteins in mango. This increase in proteins contents was due to significant enhancement in the uptake of nitrogen which is key part of amino acids and protein synthesis. Marschner ${ }^{2}$ documented that deficiency of B enhanced the formation of reactive oxygen species (ROS). Higher ROS restrict the glutathione and ascorbic acid metabolism through oxidative damage. To overcome such situation, a significant quantity of antioxidants are produced in the plants to alleviate the oxidative damages ${ }^{24}$. Low antioxidants detection in T9 and higher in $\mathrm{T} 1$ signifies that T9 alleviate the deficiency of B in plants more efficaciously as compared to other treatments. Higher permeability of roots where facilitate the uptake of $\mathrm{P}$ and $\mathrm{K}$ also enhance the uptake of water. Both $\mathrm{P}$ and $\mathrm{K}$ are widely uptake in the plants through soil solution ${ }^{18,19}$. Thus improvement in moisture contents of mango in current study also justified the better

uptake of $\mathrm{P}$ and $\mathrm{K}$. Thomidis et al. ${ }^{25}$ argued that better uptake of $\mathrm{K}$ by application of $\mathrm{B}$, promotes the firmness of fruit and total soluble solids. This optimum uptake of $K$ decrease the acidity of fruit juice regulated by balance application of $\mathrm{B}$ as a foliar and soil application ${ }^{26}$. The findings regarding improvement in total soluble solids and decrease in acidity of mango fruit juice in T9 validated the efficacious functioning of $B$ when applied as foliar application in combination with soil application.

\section{Conclusion}

It is concluded that application of boron has potential to improve the quality attributes and nutrients contents of mango. Both soil and foliar application are important for the uptake of $B$ in mango plants. However, more and efficacious results can be obtained through combined application of $B$ as foliar and soil application. It is recommended to apply B 150 g plant $^{-1}$ as a basal dose $+0.8 \%$ as foliar in combination to achieve the alleviation of B deficiency and improvement in quality and nutrients contents of mango in B deficient soils. More investigations are suggested on different mango varieties to establish and declare a narrow range of $\mathrm{B}$ application rates for mango.

\section{Declarations}


Author Contributions: Conceptualization, M.M.H.K.; N.A.; M.A.A.; methodology, M.M.H.K.; N.A.; M.A.A.; software, M.M.H.K.; N.A.; M.A.A.; validation, M.M.H.K.; N.A.; M.A.A.; formal analysis, M.M.H.K.; N.A.; M.A.A.; investigation, M.M.H.K.; N.A.; M.A.A.; resources, M.M.H.K.; N.A.; M.A.A.; data curation, M.M.H.K.; N.A.; M.A.A.; writing-original draft preparation, S.D.; S.F.; R.D.; M.M.H.; M.B.; A.E.S. M.S.; writing-review and editing, S.D.; S.F.; R.D.; M.M.H.; M.B.; A.E.S. visualization, S.D.; S.F.; R.D.; M.M.H.; M.B.; A.E.S. supervision, N.A.; project administration, M.M.H.; M.B.; A.E.S.; funding acquisition, M.M.H.; M.B.; A.E.S.;

Funding: The current work was funded by Taif University Researchers Supporting Project number (TURSP - 2020/59), Taif university, Taif, Saudi Arabia.

Acknowledgments: The authors extend their appreciation to Taif University for funding current work by Taif University Researchers Supporting Project number (TURSP - 2020/59), Taif University, Taif, Saudi Arabia.

Conflicts of Interest: The authors declare no conflict of interest.

\section{References}

1. Cakmak, I. \& Kutman, U. B. Agronomic biofortification of cereals with zinc: a review. Eur. J. Soil Sci. 69, 172-180 (2018).

2. Marschner, H. Marschner's Mineral Nutrition of Higher Plants. (Academic Press, 2011).

3. Bibi, F. et al. Effect of Foliar Application of Boron with Calcium and Potassium on Quality and Yield of Mango cv. Summer Bahisht (SB) Chaunsa. Open Agric. 4, 98-106 (2019).

4. White, P. J. \& Broadley, M. R. Chloride in Soils and its Uptake and Movement within the Plant: A Review. Ann. Bot. 88, 967-988 (2001).

5. Shirgure, P. S. Micro-irrigation systems, automation and fertigation in citrus. Sci. J. Rev. 1, 156-169 (2012).

6. Amin, G. A. M., Geweifel, H. G., Gomaa, M. A., El-kholy, M. A. \& Magda, H. M. Effect of sowing methods and fertilization on yield analysis and grain quality of wheat under new reclaimed sandy soil. J. Appl. Sci. Res. 7, 1760-1767 (2011).

7. Jankowski, K. J., Sokólski, M. \& Olszewski, J. Effect of micro-granular starter fertilizer on the micronutrient content of winter rapeseed biomass. J. Elem. 24, 449-460 (2019).

8. Anees, M., Tahir, F. M., Shahzad, J., Mahmood, N. \& Genetics, M. Effect of foliar application of micronutrients on the quality of mango (Mangifera indica L .) cv . Dusehri fruit. Mycopath 9, 25-28 (2011).

9. Esfandiari, E. \& Abdoli, M. Wheat biofortification through zinc foliar application and its effects on wheat quantitative and qualitative yields under zinc deficient stress. Yuz. Yil Univ. J. Agric. Sci. 26, 529-537 (2016).

10. Ahmad, I. et al. Assessment of various levels of potassium citrate and sucrose along with boric acid on quality and yield of Sufaid Chaunsa. Int. J. Biosci. 13, 188-195 (2018). 
11. Abdoli, M. Effects of Micronutrient Fertilization on the Overall Quality of Crops. in Plant Micronutrients Deficiency and Toxicity Management (eds. Aftab, T. \& Hakeem, K. R.) 31-71 (Springer, 2020). doi:10.1007/978-3-030-49856-6_2.

12. Aftab, T., Khan, M. M. A., Idrees, M., Naeem, M. \& Ram, M. Boron Induced Oxidative Stress, Antioxidant Defence Response and Changes in Artemisinin Content in Artemisia annua L. J. Agron. Crop Sci. 196, 423-430 (2010).

13. Dell, B. \& Huang, L. Physiological response of plants to low boron. in Plant and Soil vol. 193 103120 (1997).

14. Jatav, H. S. et al. An Overview of Micronutrients: Prospects and Implication in Crop Production. in Plant Micronutrients: Deficiency and Toxicity Management (eds. Aftab, T. \& Hakeem, K. R.) 4-5 (Springer Nature, 2020).

15. Patil, H., Tank, R. V, Bennurmath, P. \& Doni, S. Role of zinc, copper and boron in fruit crops: A review. Int. J. Chem. Stud 6, 1040-1045 (2018).

16. Robbertse, P. J., Lock, J. J., Stoffberg, E. \& Coetzer, L. A. Effect of boron on directionality of pollen tube growth in Petunia and Agapanthus. South African J. Bot. 56, 487-492 (1990).

17. Shen, Z., Liang, Y. \& Shen, K. Effect of boron on the nitrate reductase activity in oilseed rape plants. J. Plant Nutr. 16, 1229-1239 (1993).

18. Morsey, M. A. \& Taha, E. M. Effect of boron, manganese and their combination on sugar beet under El-Minia conditions. 2: concentration and uptake of N, P, K, B and Mn. Ann Agric Sci Ain Shams Univ Cairo 31, 1241-1259 (1986).

19. Misaghi, I. J. \& Grogan, R. G. Physiological basis for tipburn development in head lettuce. Phytopathology 68, 1744-1753 (1978).

20. Mozafar, A. Boron Effect on Mineral Nutrients of Maize. Agron. J. 81, 285-290 (1989).

21. Camacho-Cristóbal, J. J., Anzellotti, D. \& González-Fontes, A. Changes in phenolic metabolism of tobacco plants during short-term boron deficiency. Plant Physiol. Biochem. 40, 997-1002 (2002).

22. Redondo-Nieto, M., Pulido, L., Reguera, M., Bonilla, I. \& Bolaños, L. Developmentally regulated membrane glycoproteins sharing antigenicity with rhamnogalacturonan II are not detected in nodulated boron deficient Pisum sativum. Plant, Cell Environ. 30, 1436-1443 (2007).

23. Goldbach, H. E. \& Wimmer, M. A. Boron in plants and animals: Is there a role beyond cell-wall structure? Journal of Plant Nutrition and Soil Science vol. 170 39-48 (2007).

24. Han, S. et al. Boron deficiency decreases growth and photosynthesis, and increases starch and hexoses in leaves of citrus seedlings. J. Plant Physiol. 165, 1331-1341 (2008).

25. Thomidis, T. \& Exadaktylou, E. Effect of boron on the development of brown rot (Monilinia laxa) on peaches. Crop Prot. 29, 572-576 (2010).

26. Ekbic, H. B., Gokdemir, N. \& Erdem, H. Effects of boron on yield, quality and leaf nutrients of isabella (Vitis labrusca L.) grape cultivar. Acta Sci. Pol. Hortorum Cultus 17, 149-157 (2018). 
27. Bibi, F. et al. Effect of foliar application of boron with calcium and potassium on quality and yield of mango cv. summer bahisht (SB) Chaunsa. Open Agric. 4, (2019).

28. Gaines, T. P. \& Mitchell, G. A. Boron determination in plant tissue by the azomethine $\mathrm{H}$ method. Commun. Soil Sci. Plant Anal. 10, 1099-1108 (1979).

29. Hettiarachchi, M., Hilmers, D. C., Liyanage, C. \& Abrams, S. A. Na2EDTA Enhances the Absorption of Iron and Zinc from Fortified Rice Flour in Sri Lankan Children. J. Nutr. 134, 3031-3036 (2004).

30. Benton, J. J., B. Wolf \& H.A. Mills. Plant Analysis Handbook: A Practical Sampling, Preparation, Analysis, and Interpretation Guide - AbeBooks - Jones, J. Benton, Jr.; Wolf, Benjamin; Mills, Harry A.: 1878148001. (Micro-Macro Publishing Inc., , 1991).

31. Pratt, P. F. Potassium. in Methods of Soil Analysis: Part 2 Chemical and Microbiological Properties, 9.2 (ed. Norman, A. G.) 1022-1030 (John Wiley \& Sons, Ltd, 1965). doi:10.2134/agronmonogr9.2.c20.

32. Bremner, M. Chapter 37: Nitrogen-Total. Methods Soil Anal. Part 3. Chem. Methods-SSSA B. Ser. 5 1085-1121 (1996).

33. Rangana, S. Titratable Acidity in Manual of Fruit and Vegetable Products. (Tala McGraw. Hill Pub. Cp. Ltd., 1979).

34. DRAKE, S., LARSEN, F., FELLMAN, J. \& HIGGINS, S. Maturity, storage quality, carbohydrate, and mineral content of Goldspur apples as influenced by rootstock. J. Am. Soc. Hortic. Sci. 113, 949-952 (1988).

35. Jayaraman, J. \& Jayaraman, J. Laboratory manual in biochemistry. (Wiley Eastern Delhi, 1981).

36. Colorimetry of total phenolics with phosphomolybdic phosphotungstic acid reagents. Am. J. Enol. Vitic. 16, 144-158 (1965).

37. Spencer, J. L., Morris, M. P. \& Kennard, W. C. Vitamin C Concentration in Developing and Mature Fruits of Mango (Mangifera indica L.). Plant Physiol. 31, 79-80 (1956).

38. Steel, R. G., Torrie, J. H. \& Dickey, D. A. Principles and Procedures of Statistics: A Biometrical Approach. (McGraw Hill Book International Co., 1997).

\section{Figures}


A
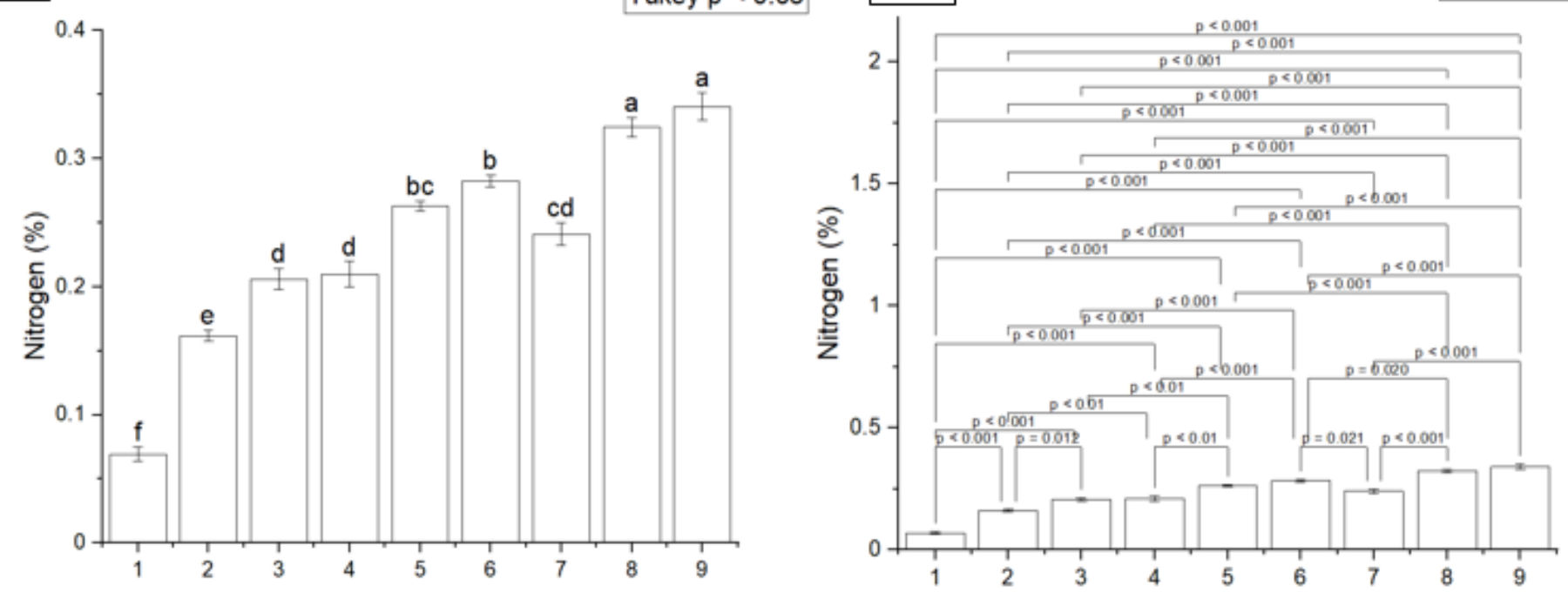

\section{Figure 1}

Effect of treatments on nitrogen concentration of mango. Different letters on bars indicated significant difference (Tukey test; $p<0.05$ ) Tukey test. $P$ values for each applied treatment are provided graph $B$ for comparison of changes in nitrogen concentration.

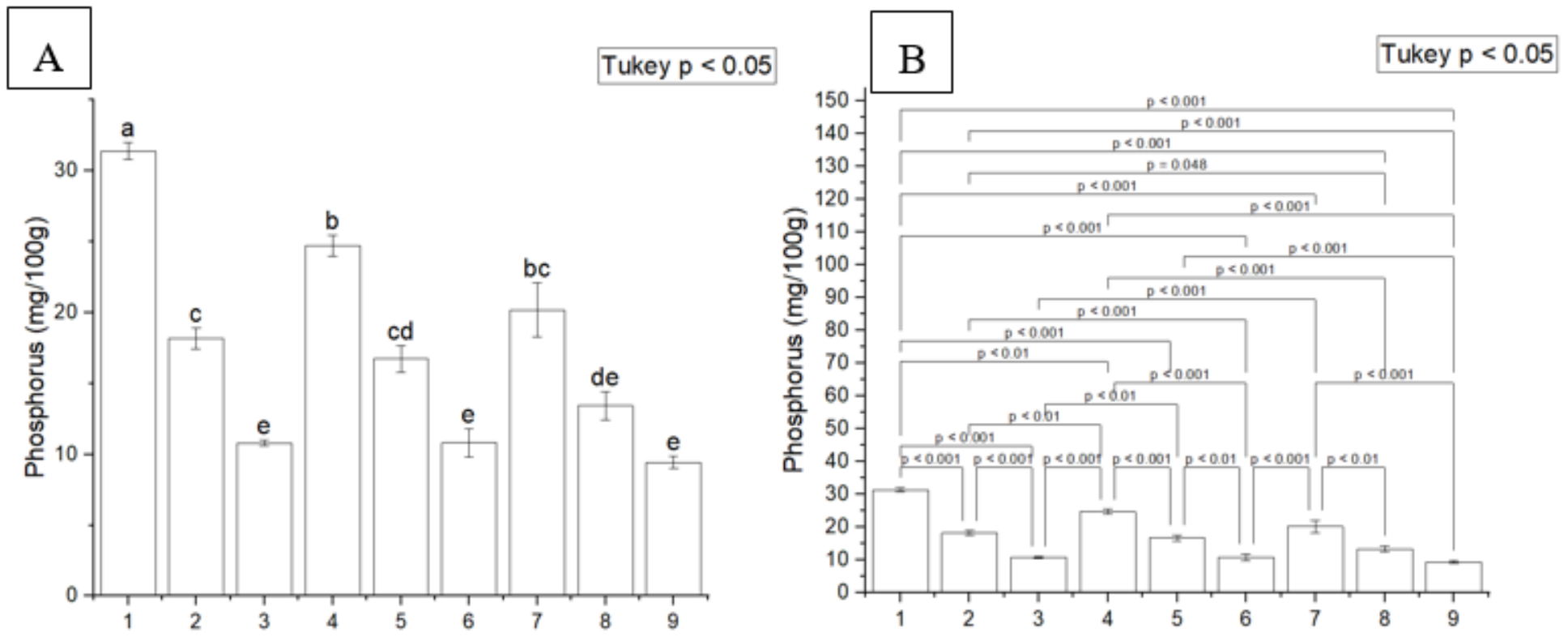

\section{Figure 2}

Effect of treatments on phosphorus concentration of mango. Different letters on bars indicated significant difference (Tukey test; $<$ < 0.05) Tukey test. P values for each applied treatment are provided graph B for comparison of changes in phosphorus concentration. 


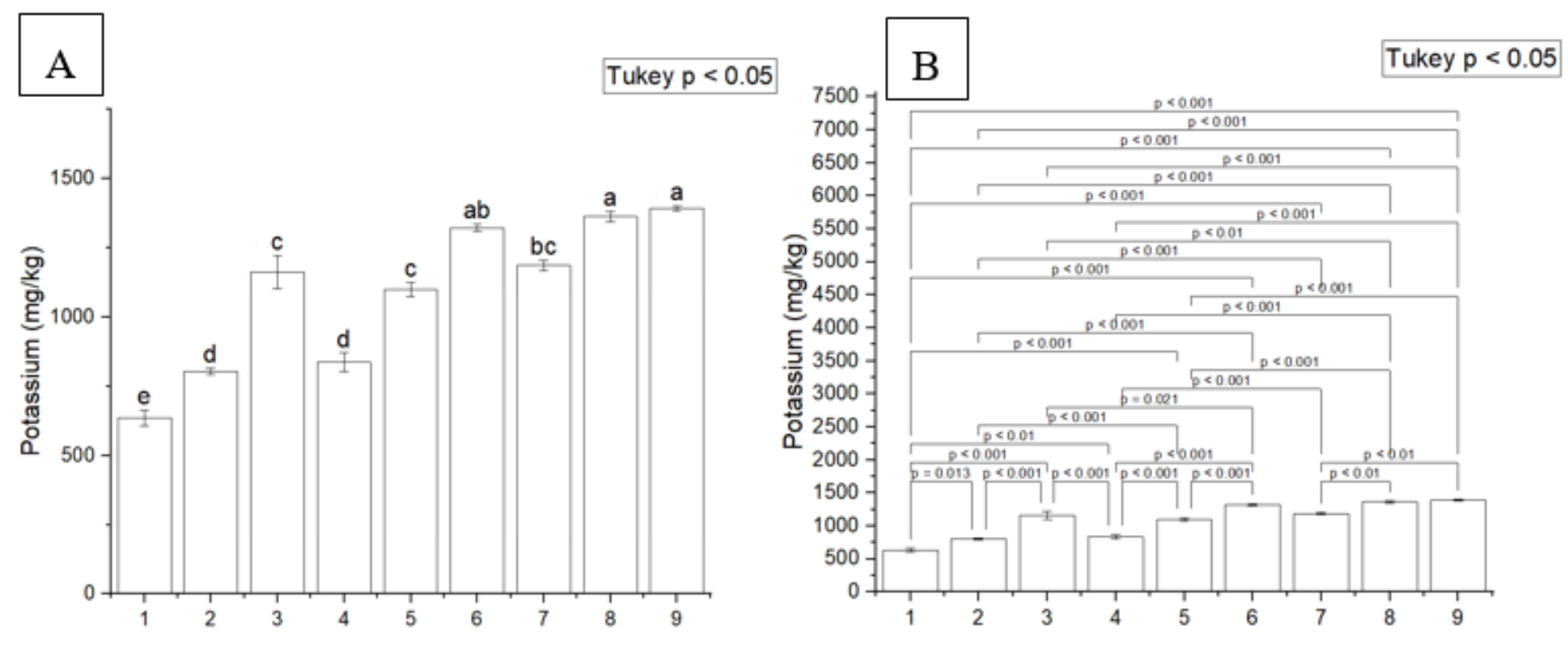

Figure 3

Effect of treatments on potassium concentration of mango. Different letters on bars indicated significant difference (Tukey test; $<<0.05$ ) Tukey test. $P$ values for each applied treatment are provided graph $B$ for comparison of changes in potassium concentration.
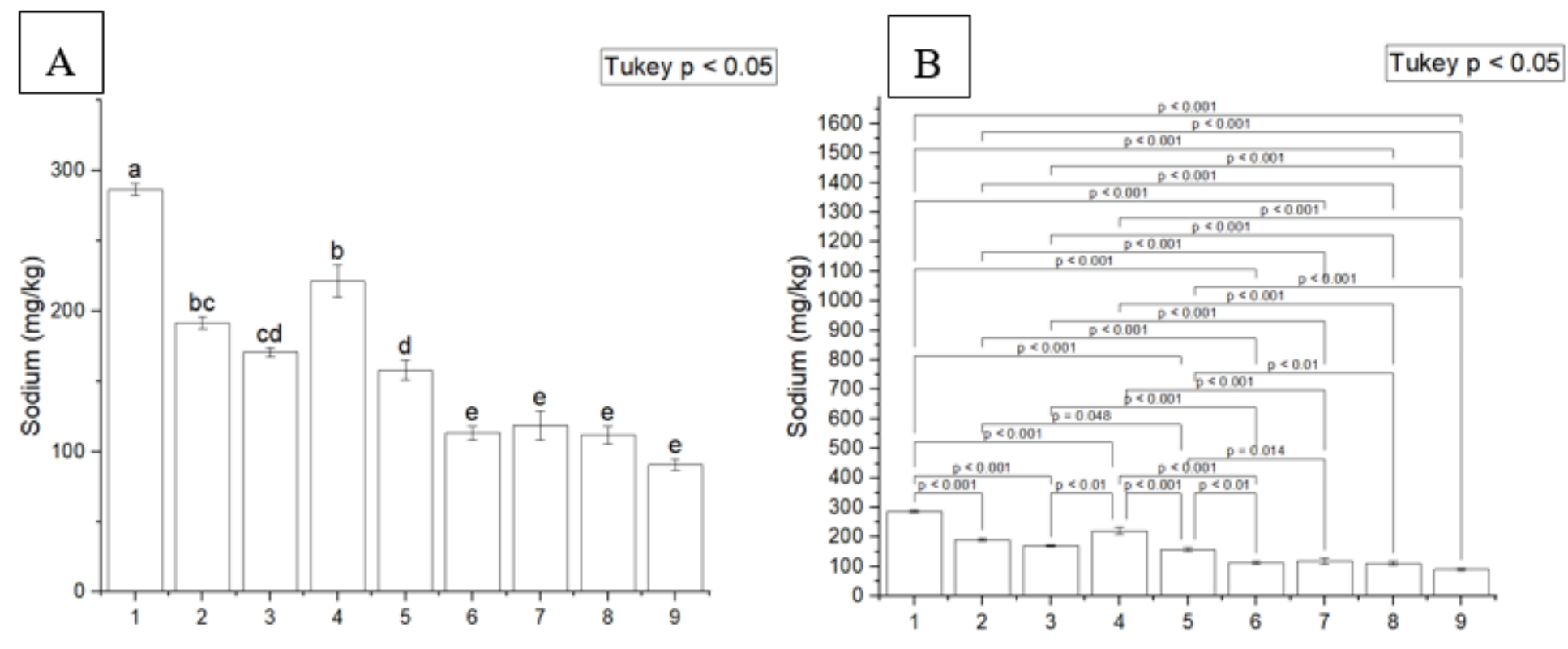

Figure 4

Effect of treatments on sodium concentration of mango. Different letters on bars indicated significant difference (Tukey test; $p<0.05$ ) Tukey test. $P$ values for each applied treatment are provided graph $B$ for comparison of changes in sodium concentration. 


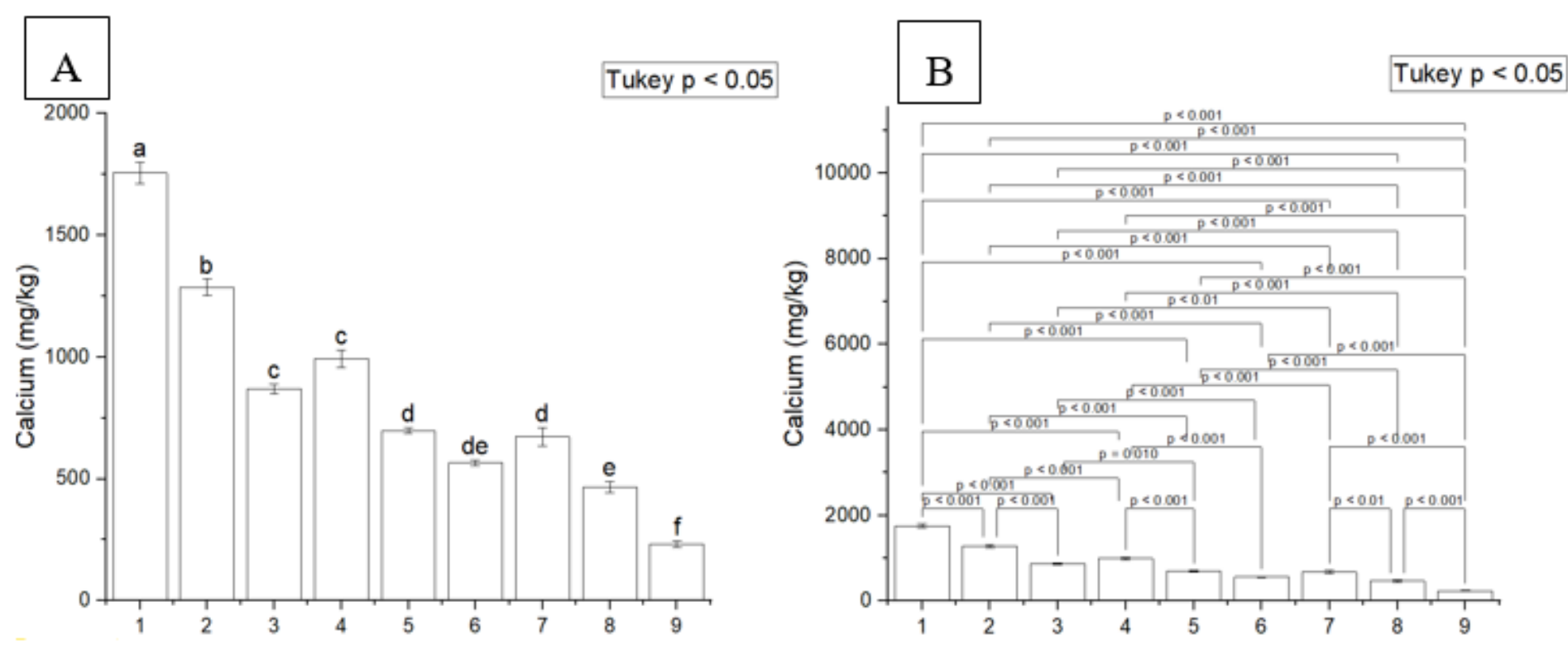

Figure 5

Effect of treatments on calcium concentration of mango. Different letters on bars indicated significant difference (Tukey test; $p<0.05$ ) Tukey test. $P$ values for each applied treatment are provided graph $B$ for comparison of changes in calcium concentration.
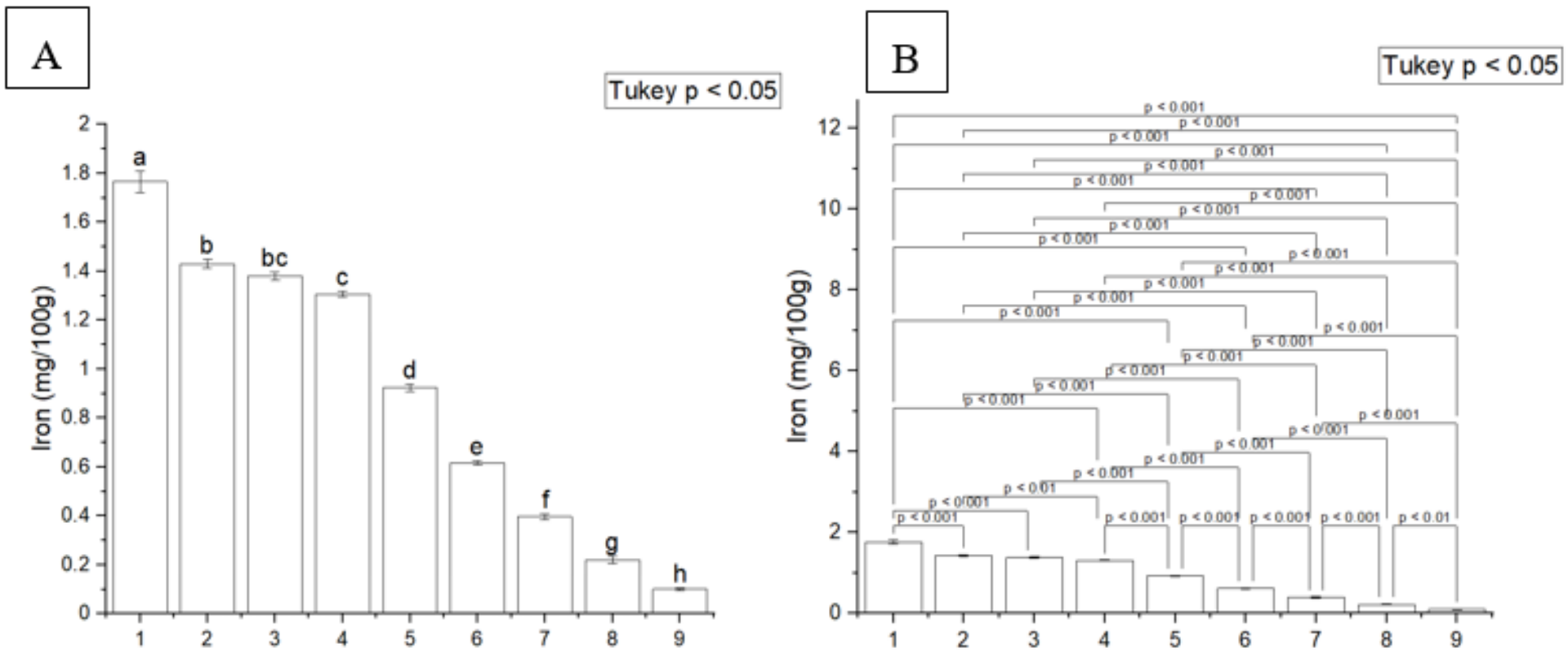

Figure 6

Effect of treatments on iron concentration of mango. Different letters on bars indicated significant difference (Tukey test; $\mathrm{p}<0.05$ ) Tukey test. $\mathrm{P}$ values for each applied treatment are provided graph $\mathrm{B}$ for comparison of changes in iron concentration. 

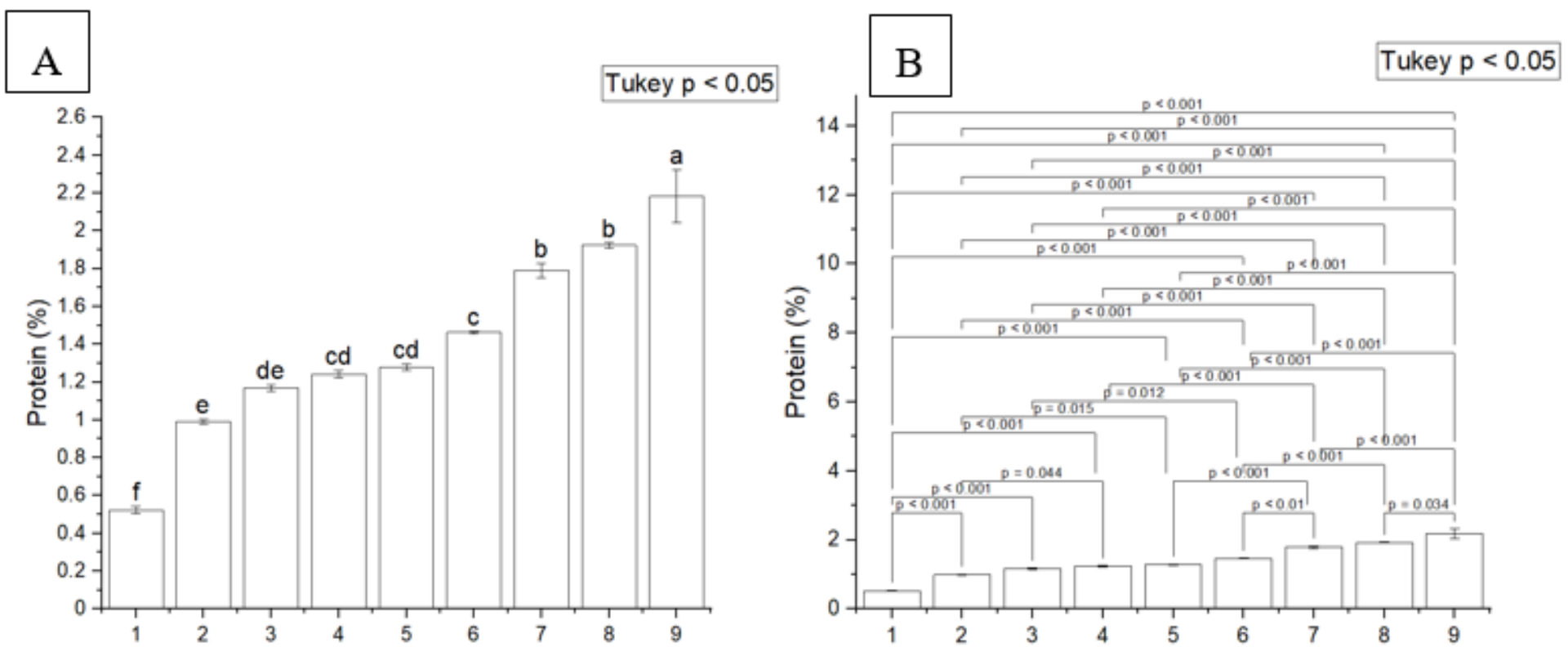

Figure 7

Effect of treatments on protein contents of mango. Different letters on bars indicated significant difference (Tukey test; $<0.05$ ) Tukey test. $P$ values for each applied treatment are provided graph B for comparison of changes in protein concentration.

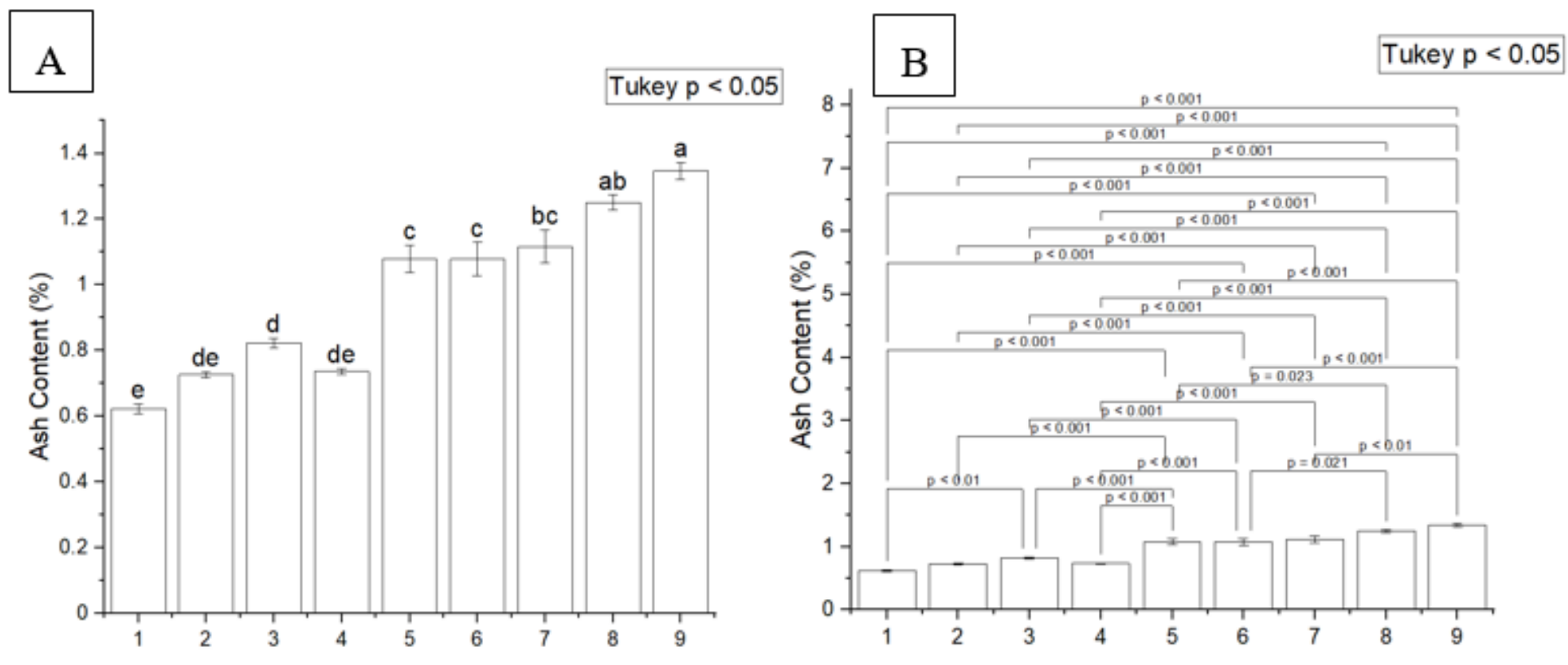

\section{Figure 8}

Effect of treatments on ash contents of mango. Different letters on bars indicated significant difference (Tukey test; $<0.05$ ) Tukey test. $P$ values for each applied treatment are provided graph $B$ for comparison of changes in ash contents. 

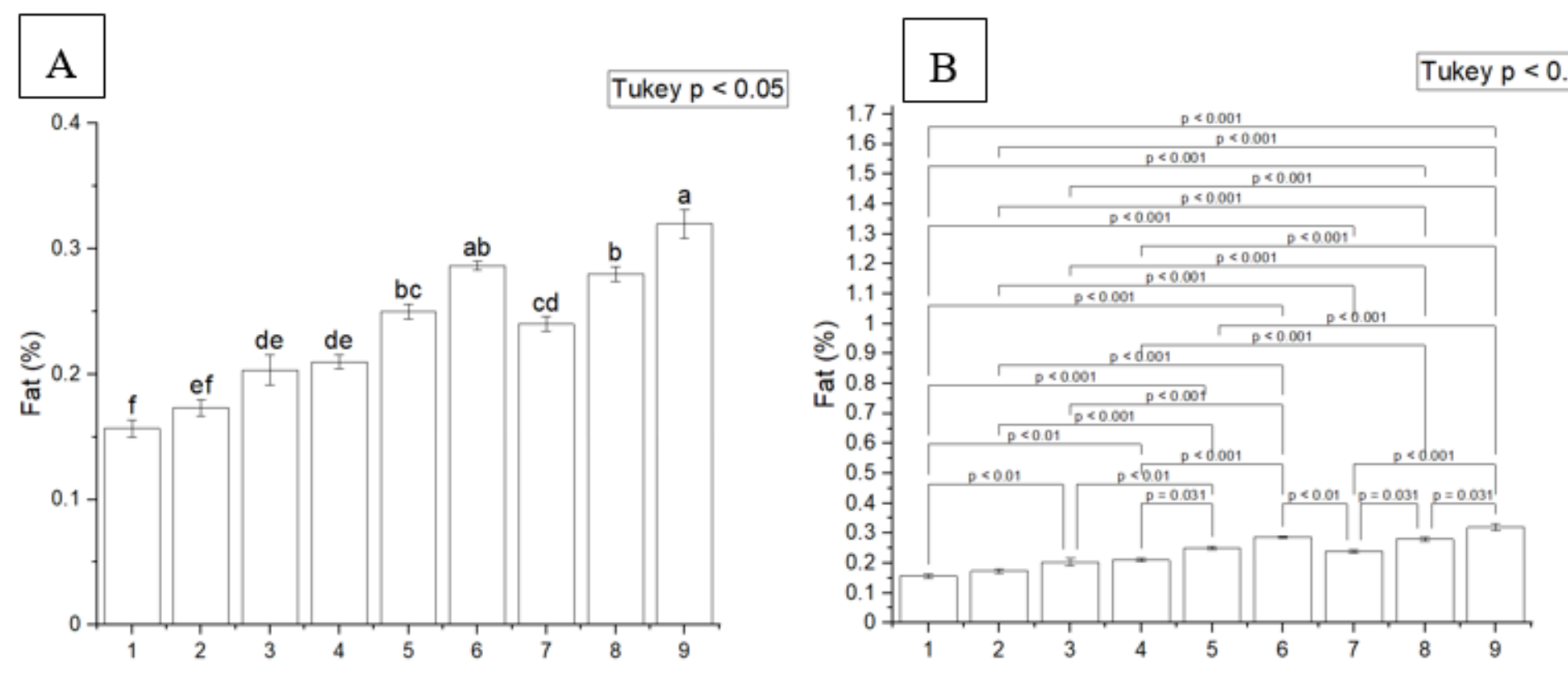

Figure 9

Effect of treatments on fats contents of mango. Different letters on bars indicated significant difference (Tukey test; $p<0.05$ ) Tukey test. $P$ values for each applied treatment are provided graph $B$ for comparison of changes in fat contents.
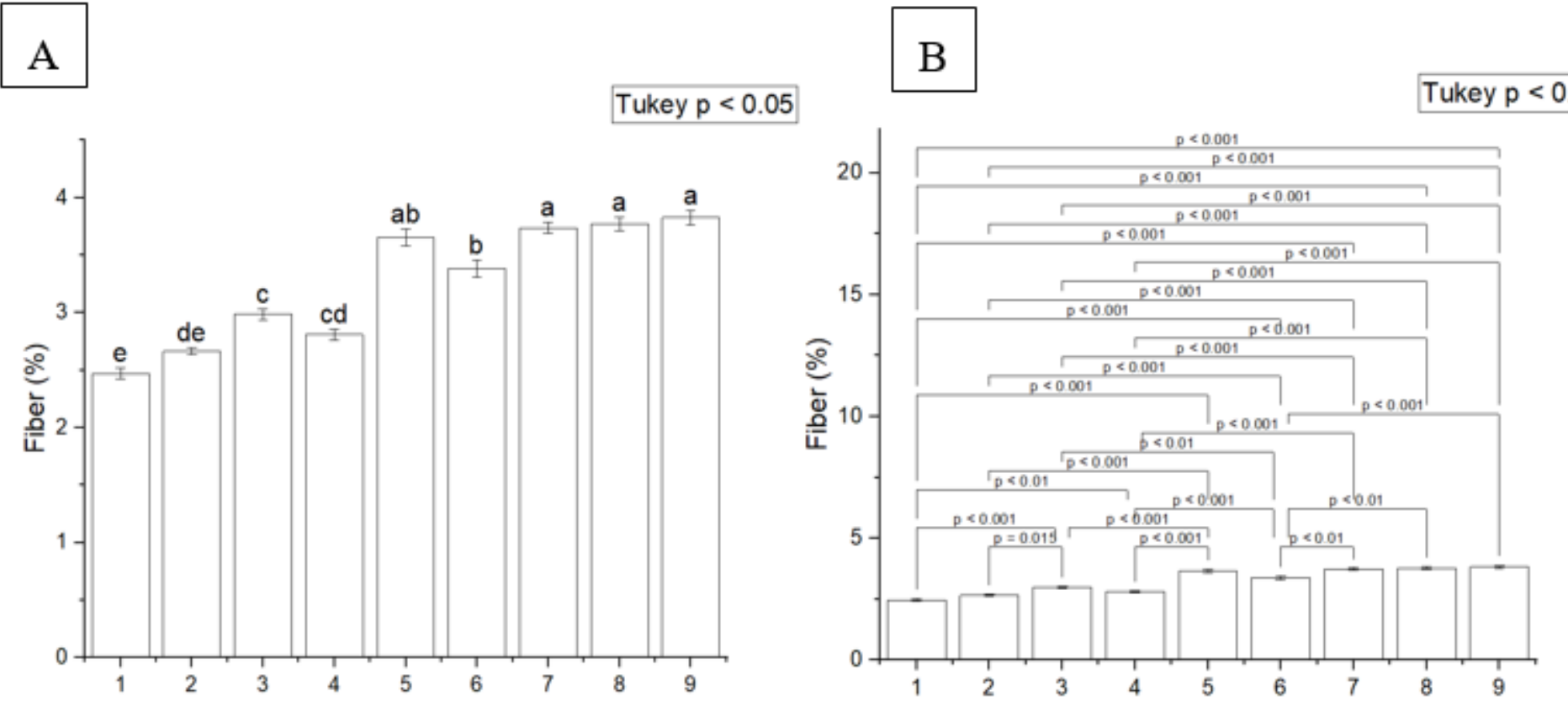

\section{Figure 10}

Effect of treatments on fiber contents of mango. Different letters on bars indicated significant difference (Tukey test; $p<0.05$ ) Tukey test. $P$ values for each applied treatment are provided graph $B$ for comparison of changes in nitrogen concentration. 

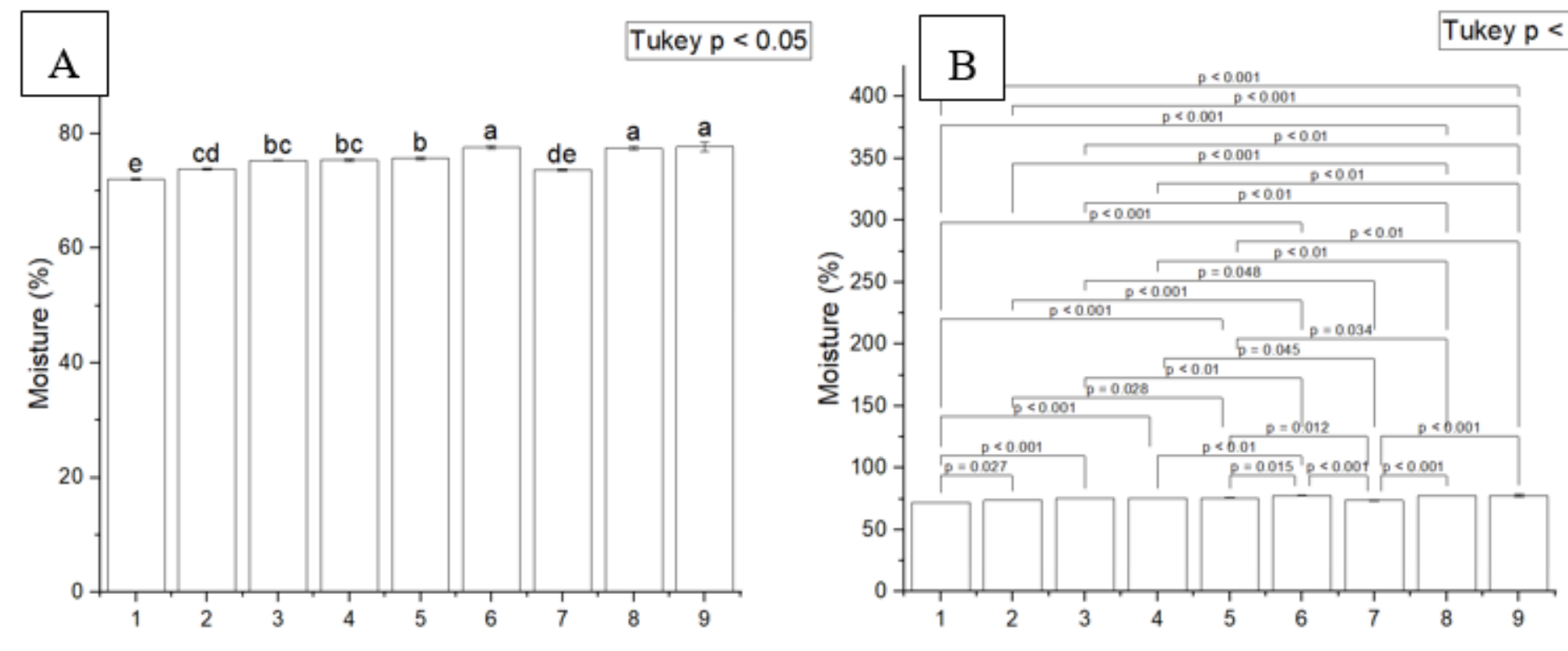

Figure 11

Effect of treatments on moisture contents of mango. Different letters on bars indicated significant difference (Tukey test; $p<0.05$ ) Tukey test. $P$ values for each applied treatment are provided graph $B$ for comparison of changes in moisture contents concentration.
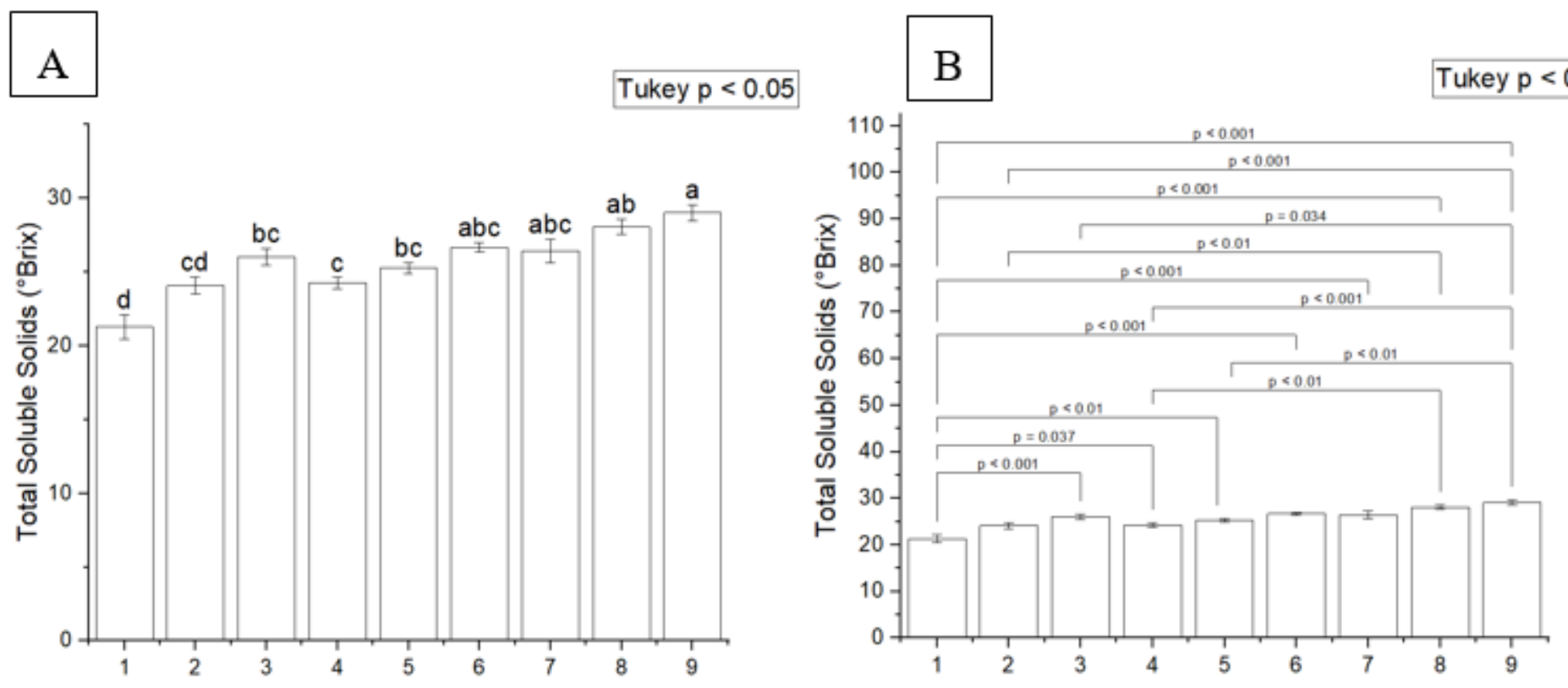

Figure 12

Effect of treatments on total soluble solids of mango. Different letters on bars indicated significant difference (Tukey test; $<0.05$ ) Tukey test. $P$ values for each applied treatment are provided graph B for comparison of changes in total soluble solids concentration. 


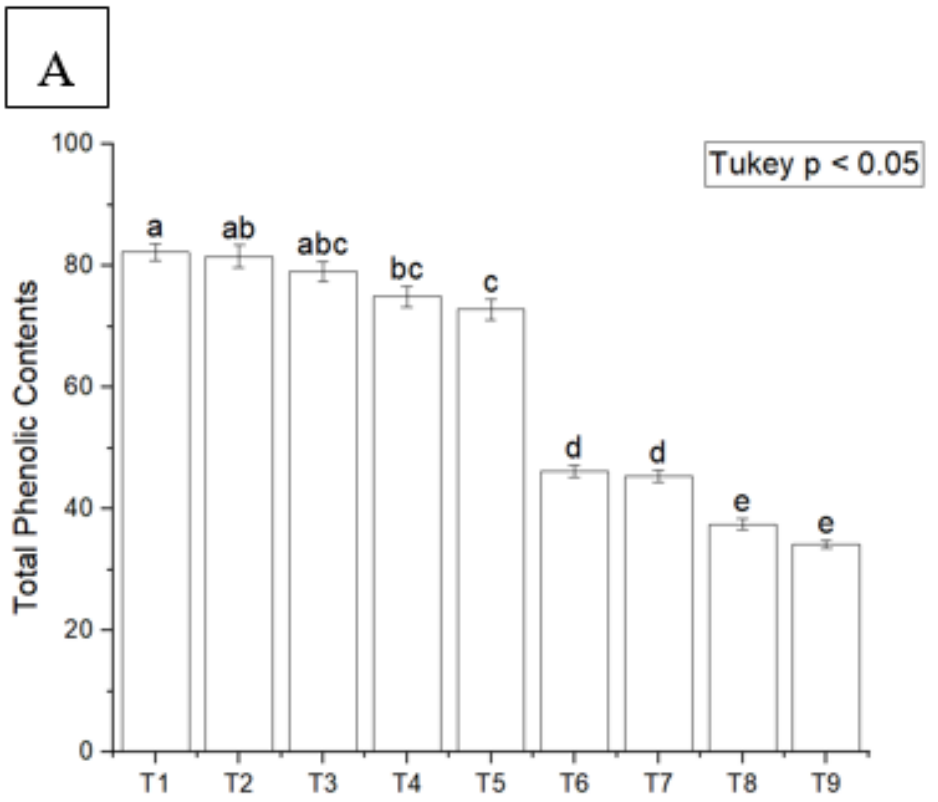

B

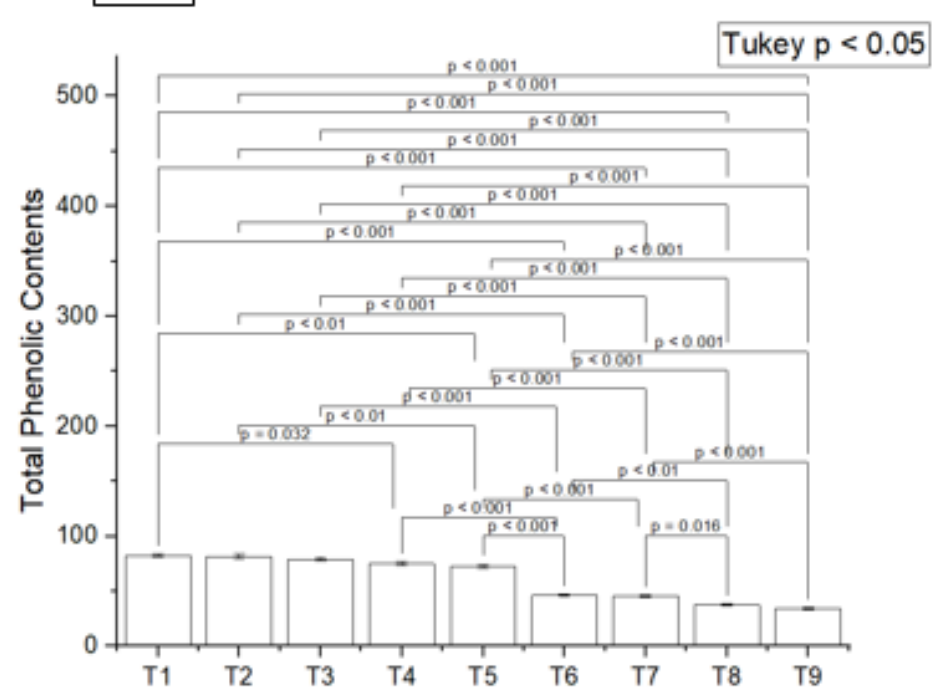

Figure 13

Effect of treatments on total phenolic contents of mango Different letters on bars indicated significant difference (Tukey test; $p<0.05$ ) Tukey test. $P$ values for each applied treatment are provided graph $B$ for comparison of changes in total phenolic contents.

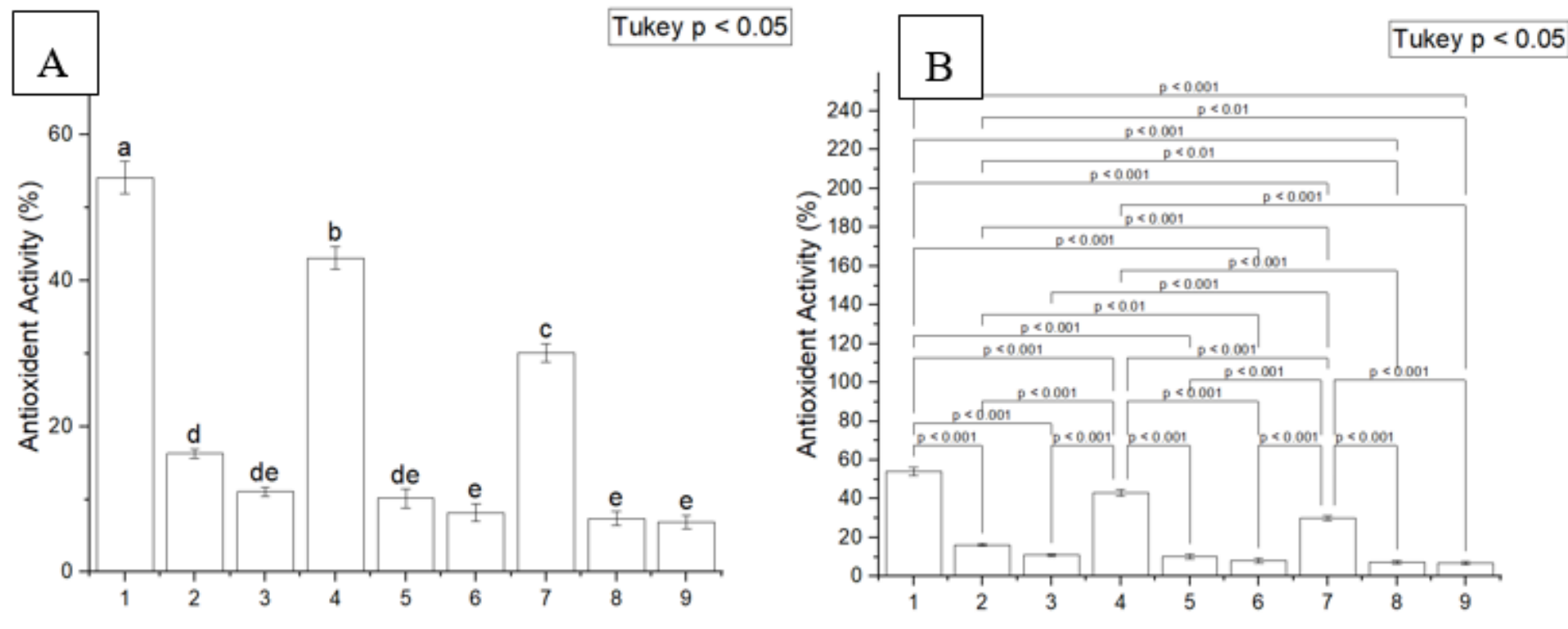

\section{Figure 14}

Effect of treatments on antioxidant activity in mango. Different letters on bars indicated significant difference (Tukey test; $p<0.05$ ) Tukey test. $P$ values for each applied treatment are provided graph $B$ for comparison of changes in antioxidant activity in concentration. 


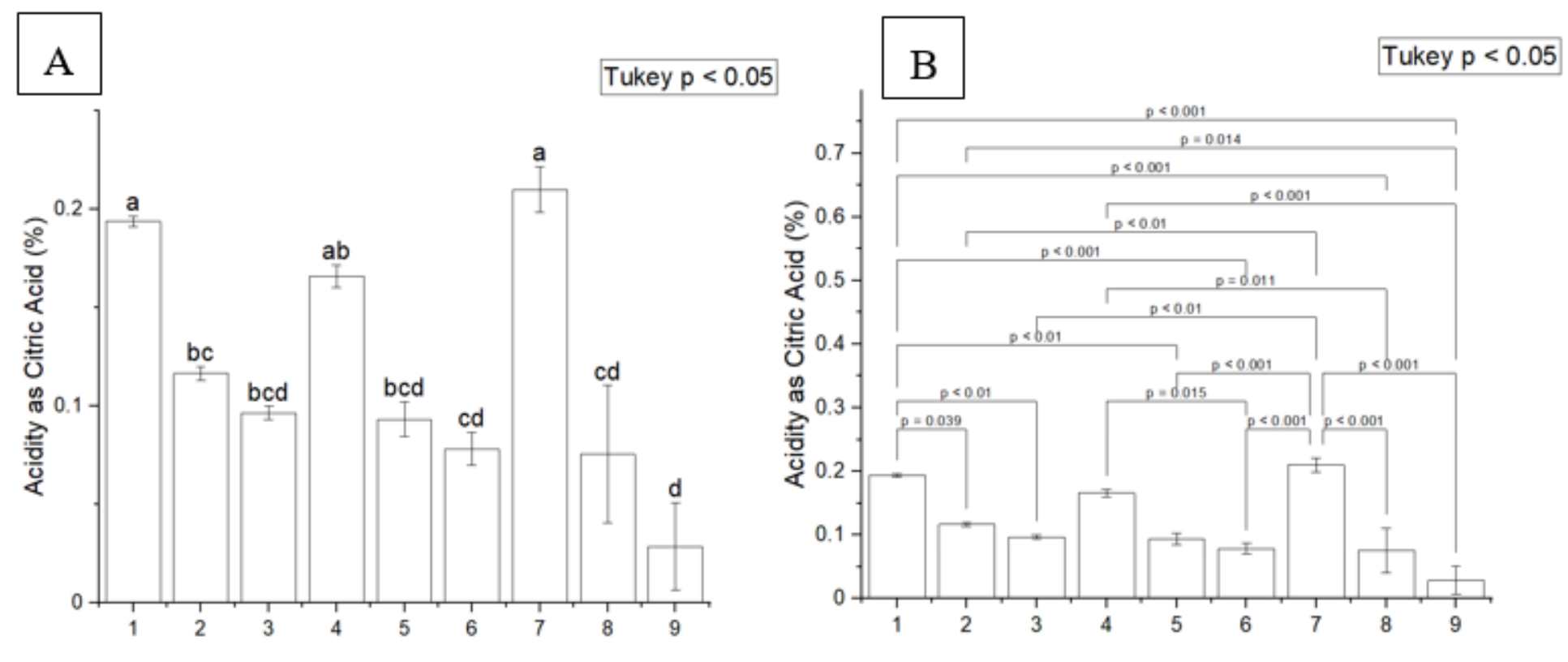

Figure 15

Effect of treatments on acidity as citric acid mango. Different letters on bars indicated significant difference (Tukey test; $<$ 0.05) Tukey test. $P$ values for each applied treatment are provided graph $B$ for comparison of changes in acidity as citric acid concentration.

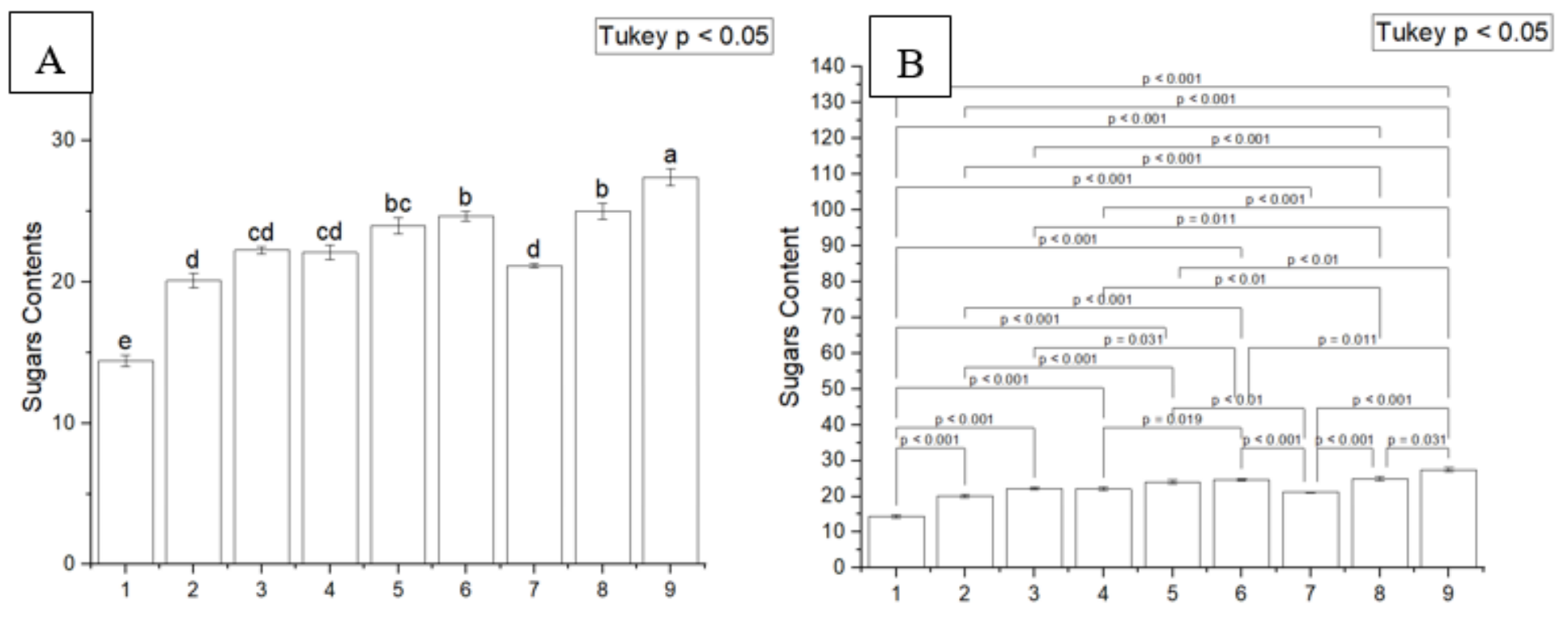

Figure 16

Effect of treatments on sugar contents of mango. Different letters on bars indicated significant difference (Tukey test; $p<0.05$ ) Tukey test. P values for each applied treatment are provided graph B for comparison of changes in sugar contents. 


\section{A}

B

Tukey $p<0.05$
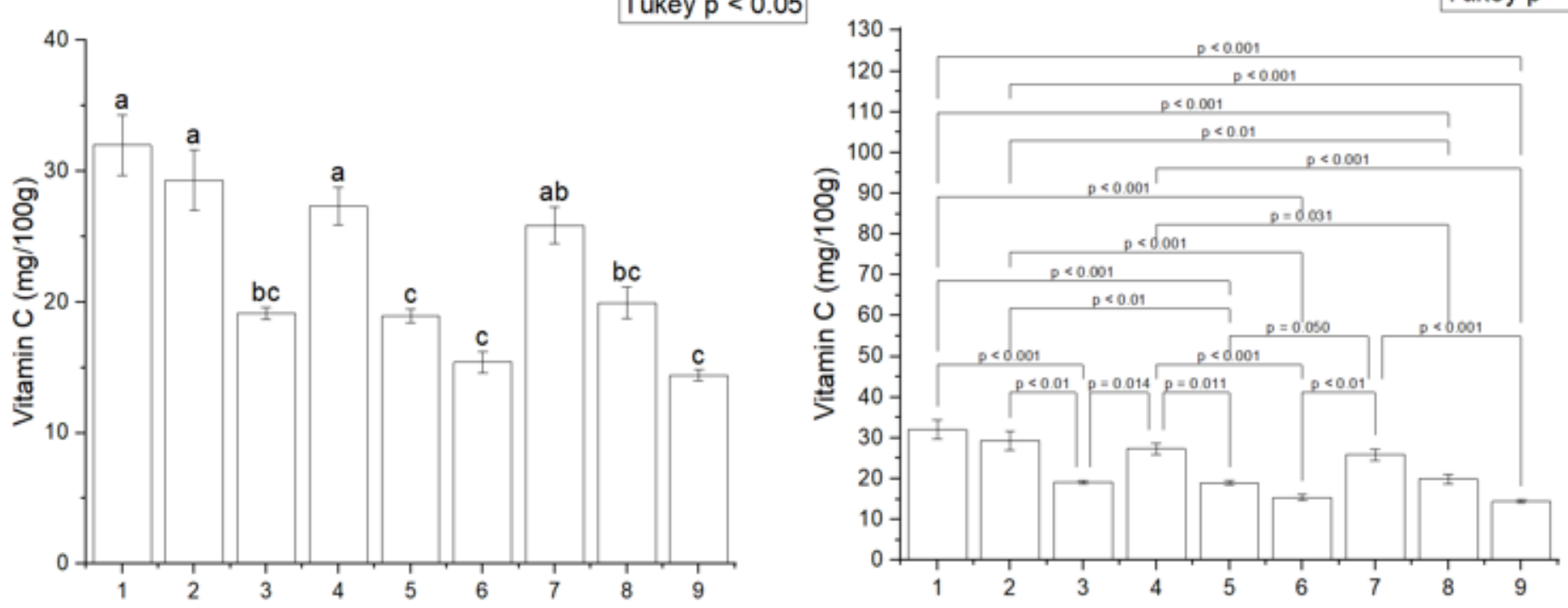

Figure 17

Effect of treatments on vitamin $\mathrm{C}$ of mango. Different letters on bars indicated significant difference (Tukey test; $p<0.05$ ) Tukey test. $P$ values for each applied treatment are provided graph B for comparison of changes in vitamin $\mathrm{C}$ concentration.



Figure 18

Pearson correlation of different mango quality attributes and nutrients contents. 


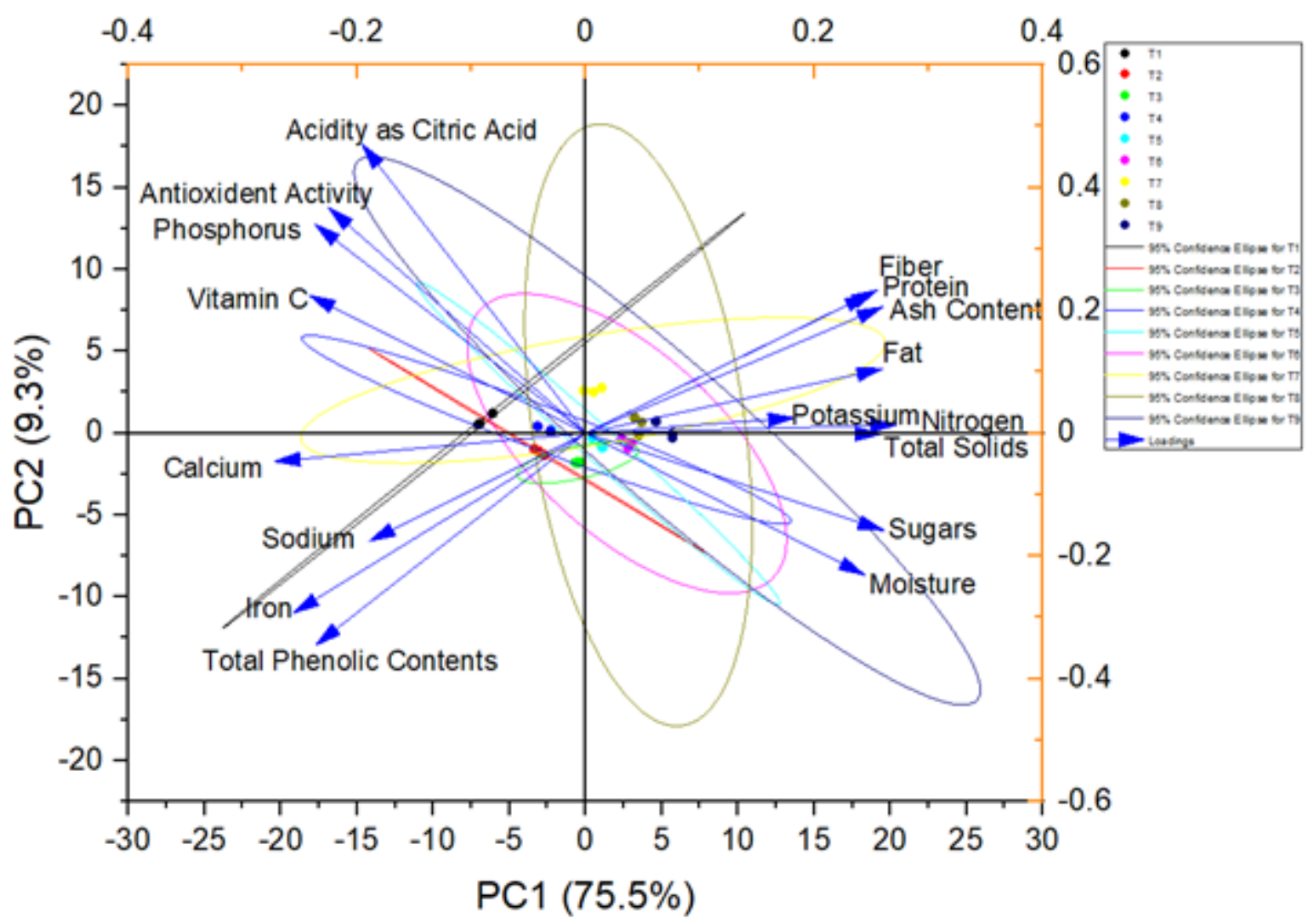

Figure 19

Principle component analyses of different mango quality attributes and nutrients contents. 